\title{
GENETIC AND ENVIRONMENTAL VARIATION OF BARLEY CHARACTERISTICS AND THE POTENTIAL OF LOCAL ORIGIN GENOTYPES FOR FOOD PRODUCTION
}

\author{
Ylle Tamm ${ }^{1,2}$ \#, Inga Jansone ${ }^{2}$, Sanita Zute ${ }^{2}$, and Ida Jakobsone ${ }^{3}$ \\ ${ }^{1}$ Estonian Crop Research Institute, Aamisepa 1, Jõgeva, EE-48309, ESTONIA, \\ ylle.tamm@etki.ee \\ 2 State Stende Cereal Breeding Institute, "Dižzemes”, Dižstende, Lībagi Civil Parish, Talsi County, LV-3258, LATVIA \\ ${ }^{3}$ Faculty of Chemistry, University of Latvia, Kr. Valdemāra iela 48, Rīga, LV-1013, LATVIA \\ \# Corresponding author
}

Communicated by Isaak Rashal

The aim of this study was to evaluate the genetic and environmental variation of yield and food quality characteristics (protein, starch, $\beta$-glucan and husk content, test weight and thousand grain weight) of covered and hulless barley genotypes in organic management conditions. Two different field experiments were carried out. In the first experiment, hulless barley genotypes 'Kornelija', 'Irbe', '1165', '1185' and the covered varieties 'Ansis' and 'Maali' were studied in two locations in Latvia and in one location in Estonia during 2014. 'Ansis', 'Kornelija', '1165' and '1185' were included in the second experiment carried out at Stende during three sequential years (2011-2013). The effect of genotype, environment (location and year) and co-effect of these factors contributed significantly to the variation in yield and grain quality traits of the barley genotypes. As a result of experimental treatments grain yield and quality traits varied by all tested factors. There were considerable differences in impact of studied sources of variation. Grain yield was influenced more by environmental factors than by genotype. Impact of genotype was highest for husk content and test weight. Integral evaluation method was carried out for comparison of barley genotypes to identify the best ones by the lowest deviation from the desired value. The covered barley variety 'Maali' showed good adaptation to different environmental conditions, having good yield, $\beta$-glucan content and high thousand grain weight. The line '1165' and variety 'Kornelija' showed best results among hulless barley varieties.

Key words: Hordeum vulgare, organic management, yield, food quality, variation.

\section{INTRODUCTION}

Barley grain is used mainly for animal feed and malt, but there is an increasing interest in barley for other food applications (Biel and Jacyno, 2013). Historically, barley has been an important food crop in many parts of the world, including the Middle East (Iran), North Africa (Marocco and Ethiopia), Northern and Eastern Europe (England, Finland, Denmark, Russia, Poland) and in Asia (Japan, India, Korea, Tibet) (Newmann and Newmann, 2006). Barley lost favour as a food grain primarily due to development of the wheat industry. Wheat bread and wheat-based breakfast cereal products have replaced much of the bakery markets for rye, oats and barley because of texture, taste, appearance, and increased availability. With increased consumer knowledge of the health benefits provided by soluble dietary fibre and other whole-grain constituents, barley foods have a good chance of regaining an important place in the human diet (Newman and Newman, 2006; Baik and Ullrich, 2008).

For food uses, barley grain is first abraded to produce pot or pearled barley, and may be further processed to grits, flakes and flour. In Western countries, pearled barley, whole, flaked, or ground, are used in breakfast cereals, stew, soups, porridge, bakery flour blends and baby foods. In Middle Eastern and African countries, barley is pearled and ground, and used in soup, flat bread and porridge (Bhatty, 1993).

Interest in barley as a food crop has been renewed, caused mainly by $\beta$-glucan effects on lowering blood cholesterol, blood pressure (Behall et al., 2004), glucose regulation and glycemic index (Cavallero et al., 2002). Several studies have shown the effectiveness of barley $\beta$-glucans in barley food products in lowering blood cholesterol (Newman et 
al., 1989; Behall et al., 2004), glucose regulation (Johansson et al., 2013) and glycemic index (Cavallero et al., 2002; Pins and Kaur, 2006). Barley has been suggested for food also due to lowering the risk of cancer and heart diseases (Ames et al., 2006; Ames and Rhymer, 2008).

Starch, protein and dietary fibre are the major components of barley kernel (Åman and Newman, 1986). Whole barley grain consists of about $650-680 \mathrm{~g} \cdot \mathrm{kg}^{-1}$ starch, $100-170$ $\mathrm{g} \cdot \mathrm{kg}^{-1}$ protein, 40-90 $\mathrm{g} \cdot \mathrm{kg}^{-1} \beta$-glucan, 20-30 $\mathrm{g} \cdot \mathrm{kg}^{-1}$ free lipids and $15-25 \mathrm{~g} \mathrm{~kg}^{-1}$ minerals (Izydorczyk et al., 2000; Quinde et al., 2004).

The naked barley cultivars generally have higher $\beta$-glucan content than the covered barley cultivars. This type of barley grain contains up to $100 \mathrm{~g} \cdot \mathrm{kg}^{-1}$ of $\beta$-glucan. (Fastnaught, 2001; Mežaka et al., 2011). The hull makes up to 10 to 15 percent of the dry weight of the barley kernel and is composed primarily of cellulose, hemicellulose, pectins, lignin, and a small amount of protein. The hull is the major contributor of crude or acid detergent fibre in the barley kernel (Bhatty, 1993).

Several studies have shown that genotype, environmental factors and fertiliser supply affect both yield and chemical composition of barley grain (Åman and Newman, 1986; Conry, 1994; Valaja et al., 1997; Thompson et al., 2012; Biel and Jacyno, 2013). A recent study carried out in Latvia at the Stende Cereal Breeding Institute showed the influence of nitrogen treatment rates to grain yield and quality of hulless barley genotypes (Bleidere et al., 2013). However, little is known of how organic management influences the food quality of barley varieties in the Baltic region. Furthermore, there is a lack of studies examining the influence of location on yield and food quality of hulless barley genotypes in the Baltic region. The aim of this study was to evaluate the variation of yield and food quality characteristics of hulless and covered spring barley genotypes and find out their potential for dietary food production under organic management.

\section{MATERIALS AND METHODS}

The field experiments. This study consists of two different field trials. In the first trial six barley genotypes were tested in three different locations during 2014 — State Stende Ce- real Breeding Institute (Latvia), State Priekuḷi Plant Breeding Institute (Latvia), and Estonian Crop Research Institute (Estonia) (trial 1). The hulless barley (HB) genotypes 'Kornelija', 'Irbe', '1165', '1185' and covered barley (CB) varieties 'Ansis' and 'Maali' were studied in this trial. 'Maali' was bred in Estonia and the other genotypes are of Latvian heritage. The second trial was carried out at Stende during three sequential years (2011-2013) (trial 2) and barley genotypes 'Ansis', 'Kornelija', '1165' and '1185' were studied.

Grain yield, 1000 kernel weight, test weight, protein, starch, husk and $\beta$-glucan content, were evaluated in trial 1 . The same characteristics, except husk content, were assessed in trial 2. All genotypes were tested on $5 \mathrm{~m}^{2}$ plots in three replications at the rate of 500 germinating seeds per $\mathrm{m}^{2}$. Both trials were carried out in organic management conditions.

Soil characteristics. Field trials in all years and locations were carried out on sod-podzolic sandy loam soil at Stende, Priekuli and on Cambisol sandy loam soil at Jõgeva. In trial 1 , the content of soil organic substances at the study site at Stende was $21.6 \mathrm{~g} \cdot \mathrm{kg}^{-1}$, the soil $\mathrm{pH}_{\mathrm{KCl}} 5.27$, the content of plant-available phosphorus $\mathrm{P}_{2} \mathrm{O}_{5} 138 \mathrm{mg} \mathrm{kg}^{-1}$, and potassium $\mathrm{K}_{2} \mathrm{O} 130 \mathrm{mg} \cdot \mathrm{kg}^{-1}$. At the study site in Priekul,i, the content of soil organic substances was $23 \mathrm{~g} \cdot \mathrm{kg}^{-1}, \mathrm{pH}_{\mathrm{KCl}} 5.8$, $\mathrm{P}_{2} \mathrm{O}_{5} 182 \mathrm{mg} \cdot \mathrm{kg}^{-1}$, and $\mathrm{K}_{2} \mathrm{O} 128 \mathrm{mg} \cdot \mathrm{kg}^{-1}$. At Jõgeva, the content of soil organic substances was $18 \mathrm{~g} \cdot \mathrm{kg}^{-1}, \mathrm{pH}_{\mathrm{KCl}} 6.2$, $\mathrm{P}_{2} \mathrm{O}_{5} 173 \mathrm{mg} \cdot \mathrm{kg}^{-1}$, and $\mathrm{K}_{2} \mathrm{O} 76 \mathrm{mg} \cdot \mathrm{kg}^{-1}$.

In the study site of trial 2 carried out at Stende, the soil organic substance content was 21-24 $\mathrm{g} \cdot \mathrm{kg}^{-1}$, soil $\mathrm{pH}_{\mathrm{KCl}}$ 5.6-6.0, $\mathrm{P}_{2} \mathrm{O}_{5}$ 147-164 $\mathrm{mg} \cdot \mathrm{kg}^{-1}$ and $\mathrm{K}_{2} \mathrm{O}$ 175-209 mg.kg during 2011-2013.

Weather conditions. Trial 1. At Priekuḷi the temperature remained mostly below the long-term average in 2014 (Table 1). It exceeded the long-term average amount only in June, by $1.3{ }^{\circ} \mathrm{C}$. The amount of precipitation was higher than the long-term average in May, June, and August. At Stende the average temperature was comparable to Priekuli, but exceeded the long-term average of Stende in May $\left(1.1{ }^{\circ} \mathrm{C}\right)$, July $\left(3.3{ }^{\circ} \mathrm{C}\right)$ and August $\left(1.6{ }^{\circ} \mathrm{C}\right)$. The total amount of precipitation was lower than in Priekuli but exceeded the local average. Monthly precipitation exceeded greatly the long-term average in June and August and remained lower than the average in May and July. At Jõgeva the average temperature of the season remained the lowest

Table 1

AVERAGE TEMPERATURES AND SUMS OF PRECIPITATION IN THE VEGETATION PERIOD AT STENDE, PRIEKUL̨I, AND JÕGEVA IN 2014

\begin{tabular}{|c|c|c|c|c|c|c|c|c|c|c|c|c|}
\hline \multirow[t]{3}{*}{ Month } & \multicolumn{6}{|c|}{ Average temperature, ${ }^{\circ} \mathrm{C}$} & \multicolumn{6}{|c|}{ Sum of precipitation, $\mathrm{mm}$} \\
\hline & \multicolumn{2}{|c|}{ Priekuḷi } & \multicolumn{2}{|c|}{ Stende } & \multicolumn{2}{|c|}{ Jõgeva } & \multicolumn{2}{|c|}{ Priekuḷi } & \multicolumn{2}{|c|}{ Stende } & \multicolumn{2}{|c|}{ Jõgeva } \\
\hline & 2014 & norm & 2014 & norm & 2014 & norm & 2014 & norm & 2014 & norm & 2014 & norm \\
\hline April & 7.1 & 9.4 & 7.1 & 4.3 & 5.9 & 8.1 & 32.1 & 40 & 30.8 & 37 & 9.9 & 37 \\
\hline May & 11.9 & 12.7 & 11.3 & 10.2 & 11.7 & 13.1 & 96.7 & 56 & 41.4 & 45 & 64.1 & 49 \\
\hline June & 13.5 & 12.2 & 13.3 & 14.2 & 13.1 & 11.7 & 108.3 & 78 & 99.4 & 57 & 157.1 & 68 \\
\hline July & 19.5 & 22.1 & 19.6 & 16.3 & 19.3 & 21.8 & 76.5 & 93 & 59.5 & 87 & 47.8 & 80 \\
\hline August & 16.7 & 17.5 & 17.1 & 15.5 & 16.5 & 17.7 & 158.2 & 88 & 119.8 & 87 & 123.0 & 88 \\
\hline Average/Sum & 13.7 & 14.8 & 13.7 & 12.1 & 13.3 & 14.5 & 471.2 & 355 & 350.9 & 313 & 401.9 & 321 \\
\hline
\end{tabular}


AVERAGE TEMPERATURES AND SUMS OF PRECIPITATION IN THE VEGETATION PERIOD AT STENDE, 2011-2013

\begin{tabular}{l|ccccc|c|c|c|c}
\hline \multirow{2}{*}{ Month } & \multicolumn{3}{|c|}{ Average temperature, ${ }^{\circ} \mathrm{C}$} & \multicolumn{4}{c}{ Sum of precipitation, mm } \\
\cline { 2 - 9 } & 2011 & 2012 & 2013 & norm & 2011 & 2012 & 2013 & norm \\
\hline April & 6.9 & 5.6 & 4.0 & 4.3 & 26.8 & 42.7 & 34.9 & 37 \\
May & 10.6 & 11.0 & 13.7 & 10.2 & 54.7 & 58.9 & 86.1 & 45 \\
June & 16.8 & 13.2 & 16.9 & 14.2 & 59.6 & 78.7 & 74.5 & 57 \\
July & 19.2 & 17.5 & 16.9 & 16.3 & 165.3 & 91.7 & 36.2 & 87 \\
August & 16.3 & 15.5 & 16.6 & 15.5 & 155.0 & 115.1 & 45.2 & 87 \\
Average/Sum & 14.0 & 12.6 & 13.6 & 12.1 & 461.4 & 387.1 & 276.9 & 313
\end{tabular}

and was in most months, except June, below the long-term average of this location. Although the total sum of precipitation was higher compared to the long-term average, there was very little rainfall in April and the amount of precipitations remained low also in July.

Trial 2. The growing season of 2011 was characterised by an average temperature above the long-term data and there were some extreme periods of drought (Table 2). Monthly average temperature exceeded the long-term data particularly in June $\left(2.6^{\circ} \mathrm{C}\right)$ and July $\left(2.9^{\circ} \mathrm{C}\right)$. The growing season of 2012 was characterised as having optimal temperature and moisture conditions, and a smaller number of sunny days. There was more precipitation than the long-term average. April of 2013 was colder than normal. The average temperature was above the long-term data also in the other months. The year 2013 was also peculiar in regard to the distribution of precipitation. The greatest amount of precipitation was observed in May and June, whereas in July and August the amount of precipitation were approximately two times lower than the average long-term data for this time of the year.

Sampling, chemical and statistical analysis. In both trials grain yield $\left(\mathrm{t} \cdot \mathrm{ha}^{-1}\right)$ was measured for each basic plot, and the samples for analysing grain quality were taken from each replication. The following grain physical traits were evaluated: 1000 kernel weight/TKW (g) by ISTA method, test weight/TW $\left(\mathrm{g} \cdot \mathrm{L}^{-1}\right)$ by an automatic grain analyser Infratec Analysis 1241. Macronutrient crude protein content $\left(\mathrm{g} \cdot \mathrm{kg}^{-1}\right)$, starch content/ST $\left(\mathrm{g} \cdot \mathrm{kg}^{-1}\right)$, and $\beta$-glucan con-

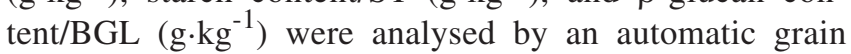
analyser Infratec Analysis 1241.

ANOVA procedures were used for statistical data analysis with the software Agrobase. In the analysis of variance, omega squared $\left(\omega^{2}\right)$ was calculated to measure the effect size or relative contributions of factors (genotype/A and year/B) (Grissom and Kim, 2012). The significance of effect of factors was determined at probability level of 0.05 .

The integral evaluation method (Martynov, 1987) was carried out to compare the tested barley phenotypes to identify the best ones by the lowest deviation from the desired value preferable for food production. The desired value and the actual value of a trait, an investment coefficient of each trait and the standard deviation are taken into account, when using this method. The integral evaluation of genotypes was carried out according to grain yield, TW, TKW, starch, protein, $\beta$-glucan and husk content. The desired value for yield and quality characteristics, except husk content, corresponded to their maximum value, but for husk content to the minimal value. The following formula was used for calculation the integral evaluation (SD):

$S D=\sum_{I=1}^{N} w_{i}\left(l_{i}-x_{i}\right) / s_{i}$

$\mathrm{w}_{\mathrm{i}}$ - investment coefficient for trait $\mathrm{i}$

$\mathrm{l}_{\mathrm{i}}$ - desired value

$\mathrm{x}_{\mathrm{i}}-$ actual value

$\mathrm{s}_{\mathrm{i}}-$ standard deviation

$\mathrm{N}$ - amount of characteristics

The minimal value of integral evaluation (SD) corresponded to the best genotype in the integral evaluation.

\section{RESULTS}

Grain yield. The variation of grain yield was significantly influenced by genotype, environment (location or year) and the co-effect of these factors in both trials. Yield varied the most by location $\left(\omega^{2}=39 \%\right)$ in trial 1 (Table 3 ) and by year $\left(\omega^{2}=54 \%\right)$ in trial 2 (Table 4). High impact of the environment may partially be explained by different meteorological conditions in locations (trial 1) and years (trial 2). Average grain yield of locations varied from $2.70 \mathrm{t} \cdot \mathrm{ha}^{-1}$ at Priekuli to $4.30 \mathrm{t} \cdot \mathrm{ha}^{-1}$ at Jõgeva in trial 1 (Table 5) and from $1.76 \mathrm{t} \cdot \mathrm{ha}^{-1}$ in 2013 to $2.94 \mathrm{t} \cdot \mathrm{ha}^{-1}$ in 2011 and 2012 in trial 2 (Table 6).

Effect of genotype in variation of yield remained lower $\left(\omega^{2}=29 \%\right.$ in trial 1 and $13 \%$ in trial 2$)$, but showed dissimilar yield potential of tested genotypes. The average grain yield of genotypes varied from 2.76 to $4.32 \mathrm{t} \mathrm{ha}^{-1}$ in trial 1 (Table 7) and 2.31 to $3.00 \mathrm{t} \cdot \mathrm{ha}^{-1}$ in trial 2 (Table 8). The CB varieties showed higher yield compared to the HB geno-

Table 3

RELATIVE IMPACT $\left(\omega^{2}, \%\right)$ OF FACTORS TO MEASURED TRAITS FOR BARLEY GENOTYPES IN DIFFERENT LOCATIONS IN TRIAL 1

\begin{tabular}{|c|c|c|c|c|c|c|c|}
\hline Source of variation & Yield & Protein & Starch & $\beta$-glucan & TW & Husk & TKW \\
\hline Genotype (A) & $29 * * *$ & $38 * * *$ & $45^{* * *}$ & $14 * * *$ & $76^{* * * *}$ & $97 * * *$ & $2 *$ \\
\hline Location (B) & $39 * * *$ & $50 * * *$ & $31 * * *$ & $29 * * *$ & $2 *$ & $1^{*}$ & $67 * * *$ \\
\hline $\mathrm{A} \times \mathrm{B}$ & $15 * * *$ & $6^{*}$ & $9 * * *$ & $48 * * *$ & $16 * * *$ & $1 *$ & $2 *$ \\
\hline
\end{tabular}

TKW, 1000 kernel weight

Significant at $* p<0.05$; ** $p<0.01$; *** $p<0.001$ 
RELATIVE IMPACT $\left(\omega^{2}, \%\right)$ OF FACTORS TO MEASURED TRAITS FOR BARLEY GENOTYPES IN DIFFERENT YEARS IN TRIAL 2

\begin{tabular}{l|c|c|c|c|c|c}
\hline Source of variation & Yield & Protein & Starch & $\beta$-glucan & TW & TKW \\
\hline Genotype (A) & $13 * * *$ & $15 * * *$ & $34 * * *$ & $30 * * *$ & $38 * * *$ & $8 * *$ \\
Year (B) & $54 * * *$ & $29 * * *$ & $7 * * *$ & $28 * * *$ & $18 * * *$ & $14 * * *$ \\
A x B & $15 * * *$ & $36 * * *$ & $50 * * *$ & $22 * * *$ & $33 * * *$ & $46 * * *$
\end{tabular}

TKW, 1000 kernel weight

Significant at * $p<0.05$;** $p<0.01$; *** $p<0.001$

Table 5

GRAIN YIELD AND QUALITY CHARACTERISTICS OF BARLEY GENOTYPES IN DIFFERENT LOCATIONS IN TRIAL 1

\begin{tabular}{l|c|c|c|c|c|c|c}
\hline Location & $\begin{array}{c}\text { Yield } \\
\mathrm{t} \cdot \mathrm{ha}^{-1}\end{array}$ & $\begin{array}{c}\text { Protein } \\
\mathrm{g} \cdot \mathrm{kg}^{-1}\end{array}$ & $\begin{array}{c}\text { Starch } \\
\mathrm{g} \cdot \mathrm{kg}^{-1}\end{array}$ & $\begin{array}{c}\beta \text {-glucan } \\
\mathrm{g} \cdot \mathrm{kg}^{-1}\end{array}$ & $\begin{array}{c}\mathrm{TW} \\
\mathrm{g} \cdot \mathrm{L}^{-1}\end{array}$ & $\begin{array}{c}\text { Husk } \\
\mathrm{g} \cdot \mathrm{kg}^{-1}\end{array}$ & $\begin{array}{c}\mathrm{TKW} \\
\mathrm{g}\end{array}$ \\
\hline Stende & 3.55 & 106 & 645 & 35 & 768 & 32 & 50.5 \\
Priekulii & 2.70 & 130 & 628 & 36 & 752 & 27 & 40.6 \\
Jõgeva & 4.30 & 106 & 642 & 44 & 759 & 27 & 44.0 \\
LSD $_{0.05}$ & 0.14 & 2 & 3 & 1 & 6 & 2 & 0.6
\end{tabular}

TW, test weight

TKW, 1000 kernel weight

Table 6

GRAIN YIELD AND QUALITY CHARACTERISTICS OF BARLEY GENOTYPES IN DIFFERENT YEARS IN TRIAL 2

\begin{tabular}{l|c|c|c|c|c|c}
\hline \multicolumn{1}{c|}{ Year } & $\begin{array}{c}\text { Yield } \\
\mathrm{t} \cdot \mathrm{ha}^{-1}\end{array}$ & $\begin{array}{c}\text { Protein } \\
\mathrm{g} \cdot \mathrm{kg}^{-1}\end{array}$ & $\begin{array}{c}\text { Starch } \\
\mathrm{g} \cdot \mathrm{kg}^{-1}\end{array}$ & $\begin{array}{c}\beta \text {-glucan } \\
\mathrm{g} \cdot \mathrm{kg}^{-1}\end{array}$ & $\begin{array}{c}\mathrm{TW} \\
\mathrm{g} \cdot \mathrm{L}^{-1}\end{array}$ & $\begin{array}{c}\text { TKW } \\
\mathrm{g}\end{array}$ \\
\hline 2011 & 2.94 & 111 & 633 & 28 & 728 & 43.3 \\
2012 & 2.94 & 97 & 641 & 41 & 765 & 43.9 \\
2013 & 1.76 & 98 & 640 & 41 & 707 & 41.6 \\
LSD $_{0.05}$ & 0.15 & 3 & 2 & 2 & 10 & 0.8
\end{tabular}

TW, test weight

TKW, 1000 kernel weight

types in both trials. The variety 'Maali' demonstrated the best yield level (4.32 $\left.\mathrm{t} \cdot \mathrm{ha}^{-1}\right)$ in trial 1 and 'Ansis' (3.00 $\mathrm{t} \cdot \mathrm{ha}^{-1}$ ) in trial 2. Among the HB genotypes, line '1165' had the highest yield $\left(3.45 \mathrm{t} \cdot \mathrm{ha}^{-1}\right)$ in trial 1 and '1185' (2.56 $\mathrm{t} \cdot \mathrm{ha}^{-1}$ ) in trial 2. The co-effect of two factors showed different reaction of genotypes to various growing conditions.

Grain food quality traits. Analysis of variance indicated different impact of factors to grain quality traits in trial 1 and trial 2. Variation of protein was determined the most by location $\left(\omega^{2}=50 \%\right)$ in trial 1 and by co-effect of genotype and year $\left(\omega^{2}=38 \%\right)$ in trial 2 . Average protein content was the highest at Priekuli in trial 1, exceeding the level at Stende and Jõgeva significantly by $24 \mathrm{~g} \cdot \mathrm{kg}^{-1}$. The differences in protein levels between the years in trial 2 remained smaller than between locations in trial 1. The variety 'Kornelija' showed the highest level of protein in both trials. The protein content of the HB genotypes was mostly superior compared to that of $\mathrm{CB}$ varieties.
GRAIN YIELD AND QUALITY CHARACTERISTICS OF BARLEY GENOTYPES AS AN AVERAGE OF LOCATIONS IN TRIAL 1

\begin{tabular}{l|c|c|c|c|c|c|c}
\hline $\begin{array}{c}\text { Geno- } \\
\text { type }\end{array}$ & $\begin{array}{c}\text { Yield } \\
\mathrm{t} \cdot \mathrm{ha}^{-1}\end{array}$ & $\begin{array}{c}\text { Protein } \\
\mathrm{g} \cdot \mathrm{kg}^{-1}\end{array}$ & $\begin{array}{c}\text { Starch } \\
\mathrm{g} \cdot \mathrm{kg}^{-1}\end{array}$ & $\begin{array}{c}\beta \text {-glucan } \\
\mathrm{g} \cdot \mathrm{kg}^{-1}\end{array}$ & $\begin{array}{c}\mathrm{TW} \\
\mathrm{g} \cdot \mathrm{L}^{-1}\end{array}$ & $\begin{array}{c}\text { Husk } \\
\mathrm{g} \cdot \mathrm{kg}^{-1}\end{array}$ & $\begin{array}{c}\mathrm{TKW} \\
\mathrm{g}\end{array}$ \\
\hline Ansis & 3.92 & 101 & 635 & 36 & 700 & 76 & 44.6 \\
Kornelija & 2.76 & 134 & 625 & 37 & 791 & 6 & 47.5 \\
Irbe & 3.22 & 115 & 649 & 40 & 821 & 3 & 41.6 \\
1185 & 3.41 & 114 & 644 & 34 & 747 & 1 & 44.0 \\
1165 & 3.45 & 109 & 647 & 41 & 791 & 9 & 44.3 \\
Maali & 4.32 & 109 & 630 & 42 & 710 & 70 & 48.1 \\
LSD $_{0.05}$ & 0.19 & 3 & 4 & 2 & 9 & 2 & 0.9 \\
\hline
\end{tabular}

TW, test weight

Table 8

GRAIN YIELD AND QUALITY CHARACTERISTICS OF BARLEY GENOTYPES AS AN AVERAGE OF YEARS IN TRIAL 2

\begin{tabular}{l|c|c|c|c|c|c}
\hline Genotype & $\begin{array}{c}\text { Yield } \\
\mathrm{t} \cdot \mathrm{ha}^{-1}\end{array}$ & $\begin{array}{c}\text { Protein } \\
\mathrm{g} \cdot \mathrm{kg}^{-1}\end{array}$ & $\begin{array}{c}\text { Starch } \\
\mathrm{g} \cdot \mathrm{kg}^{-1}\end{array}$ & $\begin{array}{c}\beta \text {-glucan } \\
\mathrm{g} \cdot \mathrm{kg}^{-1}\end{array}$ & $\begin{array}{c}\mathrm{TW} \\
\mathrm{g} \cdot \mathrm{L}^{-1}\end{array}$ & $\begin{array}{c}\mathrm{TKW} \\
\mathrm{g}\end{array}$ \\
\hline 1185 & 2.56 & 97 & 644 & 32 & 729 & 42.7 \\
Kornelija & 2.31 & 108 & 640 & 37 & 747 & 42.4 \\
1165 & 2.33 & 105 & 643 & 36 & 776 & 42.4 \\
Ansis & 3.00 & 98 & 625 & 41 & 681 & 44.3 \\
LSD $_{0.05}$ & 0.18 & 3 & 3 & 3 & 12 & 0.9
\end{tabular}

TW, test weight

TKW, 1000 kernel weight

Starch content was mostly influenced by genotype $\left(\omega^{2}=\right.$ $45 \%$ ) in trial 1 and by co-effect of genotype and location $\left(\omega^{2}=50 \%\right)$ in trial 2. Starch content was the lowest at Priekuli $\left(628 \mathrm{~g} \cdot \mathrm{kg}^{-1}\right)$ in trial 1 and in $2011\left(633 \mathrm{~g} \cdot \mathrm{kg}^{-1}\right)$ in trial 2. The variety 'Kornelija', which had the highest protein, showed the lowest level of starch content. The variety 'Irbe' demonstrated the highest starch content $\left(649 \mathrm{~g} \cdot \mathrm{kg}^{-1}\right)$ in trial 1 and line '1165' $\left(643 \mathrm{~g} \cdot \mathrm{kg}^{-1}\right)$ in trial 2.

The variation of $\beta$-glucan content was mostly determined by the co-effect of genotype and location $\left(\omega^{2}=48 \%\right)$ followed by the effect of location $\left(\omega^{2}=29 \%\right)$ in trial 1 . The impact of genotype, year and co-effect of these factors to the variance of $\beta$-glucan content remained almost equal in trial 2. The average content of $\beta$-glucan was the highest (44 $\left.\mathrm{g} \cdot \mathrm{kg}^{-1}\right)$ at Jõgeva and remained the lowest $\left(35 \mathrm{~g} \cdot \mathrm{kg}^{-1}\right)$ at Stende in trial 1 . The level of $\beta$-glucan remained significantly lower in $2011\left(28 \mathrm{~g} \cdot \mathrm{kg}^{-1}\right)$, compared to the results of 2012 and 2014 (41 $\left.\mathrm{g} \cdot \mathrm{kg}^{-1}\right)$. The CB variety 'Maali' showed the highest level of $\beta$-glucan $\left(42 \mathrm{~g} \cdot \mathrm{kg}^{-1}\right)$ followed by $\mathrm{HB}$ genotypes '1165' (41 g. $\left.\mathrm{kg}^{-1}\right)$ and 'Irbe' $\left(40 \mathrm{~g} \cdot \mathrm{kg}^{-1}\right)$. The variety 'Ansis' demonstrated the highest content of $\beta$-glucan $\left(41 \mathrm{~g} \cdot \mathrm{kg}^{-1}\right)$ in trial 2 .

Grain husk content was higher at Stende $\left(32 \mathrm{~g} \cdot \mathrm{kg}^{-1}\right)$ than at Priekuḷi and Jõgeva $\left(27 \mathrm{~g} \cdot \mathrm{kg}^{-1}\right)$. The husk content of $\mathrm{HB}$ genotype remained between $3-10 \mathrm{~g} \cdot \mathrm{kg}^{-1}$. 'Ansis' showed the lowest husk content $\left(3 \mathrm{~g} \cdot \mathrm{kg}^{-1}\right)$ among tested genotypes. 
Among CB genotypes 'Maali' had lower husk content (70 $\left.\mathrm{g} \cdot \mathrm{kg}^{-1}\right)$ than 'Ansis' $\left(76 \mathrm{~g} \cdot \mathrm{kg}^{-1}\right)$.

Variation of TW was mainly determined by genotype $\left(\omega^{2}=\right.$ $76 \%$ ), while the impact of location remained marginal $\left(\omega^{2}=\right.$ $2 \%)$ in trial 1 . TW was influenced the most by genotype $\left(\omega^{2}\right.$ $=38 \%)$ also in trial 2 , but the share of year $\left(1^{2}=18 \%\right)$ and their co-effect $\left(\omega^{2}=33 \%\right)$ in variation was higher than in trial 1. Average TW at Stende $\left(768 \mathrm{~g} \cdot \mathrm{L}^{-1}\right)$ was significantly higher than at Priekuli $\left(752 \mathrm{~g} \cdot \mathrm{L}^{-1}\right)$ and Jõgeva $\left(759 \mathrm{~g} \cdot \mathrm{L}^{-1}\right)$ but superiority remained quite small. The level of TW in $2012\left(765 \mathrm{~g} \cdot \mathrm{L}^{-1}\right)$ was much higher than in $2011\left(728 \mathrm{~g} \cdot \mathrm{L}^{-1}\right)$ and $2013\left(707 \mathrm{~g} \cdot \mathrm{L}^{-1}\right)$. All the HB genotypes sowed had higher level of TW compared to that of the CB varieties. The variety 'Irbe' had the highest TW $\left(821 \mathrm{~g} \cdot \mathrm{L}^{-1}\right)$ in trial 1 and breed '1165' $\left(776 \mathrm{~g} \cdot \mathrm{L}^{-1}\right)$ in trial 2.

Variation of TKW was mainly determined by location $\left(\omega^{2}=\right.$ $67 \%$ ) in trial 1, and the share of other factors remained marginal. Co-effect of genotype and year was the main source of variation $\left(\omega^{2}=46 \%\right)$ for TKW in trial 2 . There were great differences between the levels of average TKW in locations in trial 1 . TKW was the highest $(50.5 \mathrm{~g})$ at Stende and lowest $(40.6 \mathrm{~g})$ at Priekuli. In trial 2 the TKW was in 2013 (41.6 g) significantly lower than that in 2011 (43.3 g) and 2012 (43.9 g). The CB variety 'Maali' showed the highest TKW (48.1 g) in trial 1 followed by the HB variety 'Kornelija' (47.5 g). The CB variety 'Ansis' had the highest TKW (44.3 g) in trial 2.

Ranking genotypes by integral evaluation method. The tested genotypes were analysed by integral evaluation method according to grain yield and quality traits simultaneously with the aim to identify the varieties having the lowest deviation from the desired value for food production. The $\mathrm{CB}$ variety 'Maali' received the best ranking $(\mathrm{SD}=9.8)$ in trial 1 followed by the HB genotypes - the line '1165' $(\mathrm{SD}=12.0)$ and 'Kornelija' ( $\mathrm{SD}=12.1)$ (Fig. 1), leaving behind the HB genotypes. 'Maali' showed the highest level of grain yield $\left(4.32 \mathrm{t} \cdot \mathrm{ha}^{-1}\right)$, content of $\beta$-glucan $\left(42 \mathrm{~g} \cdot \mathrm{kg}^{-1}\right)$ and TKW (48.1 g) as an average of locations. The TW (710 $\left.\mathrm{g} \cdot \mathrm{L}^{-1}\right)$, protein $\left(109 \mathrm{~g} \cdot \mathrm{kg}^{-1}\right)$ and starch content $\left(630 \mathrm{~g} \cdot \mathrm{kg}^{-1}\right)$ of the variety remained inferior compared to most of the HB genotypes. The CB variety 'Maali' showed good adaptation to different environmental conditions. The line ' 1165 ' demonstrated the highest yield $\left(3.45 \mathrm{t} \cdot \mathrm{ha}^{-1}\right)$ among the HB genotypes in trial 1 . The hulless line ' $1165^{\prime}$ had also a good level of $\beta$-glucan $\left(41 \mathrm{~g} \cdot \mathrm{kg}^{-1}\right)$ and starch $\left(647 \mathrm{~g} \cdot \mathrm{kg}^{-1}\right)$ con-

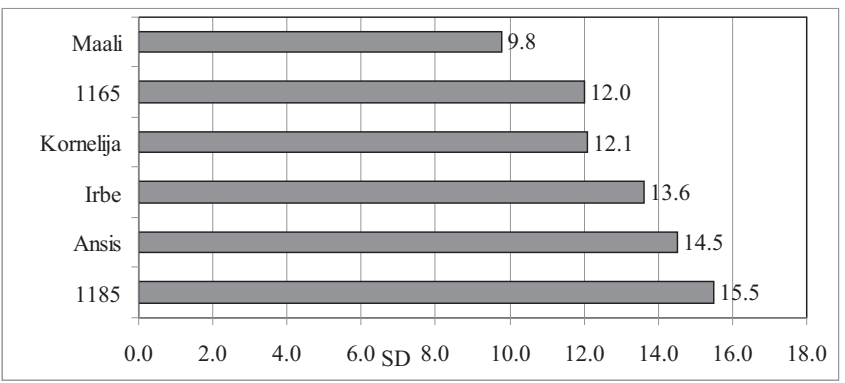

Fig. 1. Assessment of barley varieties by integral evaluation method (SD) for food production (trial 1).

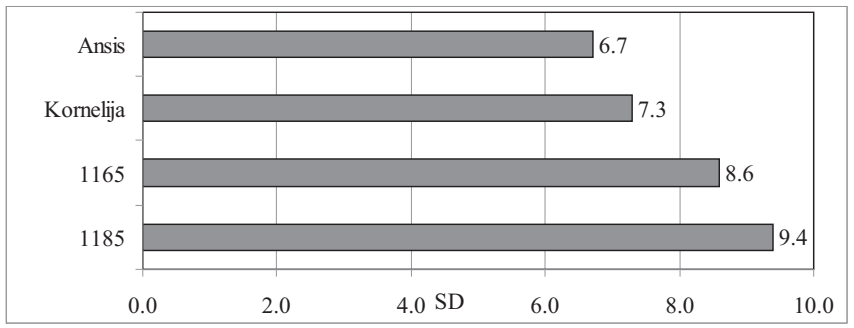

Fig. 2. Assessment of barley varieties by integral evaluation method (SD) for food production (trial 2).

tent. 'Kornelija' showed the highest protein content (134 $\left.\mathrm{g} \cdot \mathrm{kg}^{-1}\right)$, but the grain yield of the variety $\left(2.76 \mathrm{t} \cdot \mathrm{ha}^{-1}\right)$ remained the lowest in trial 1 .

The CB variety 'Ansis' ranked first by integral evaluation $(\mathrm{SD}=6.7)($ Fig. 2$)$ followed by the HB genotype 'Kornelija' $(\mathrm{SD}=7.3)$. 'Ansis' showed the best yield $\left(3.00 \mathrm{t} \mathrm{ha}^{-1}\right)$ and $\beta$-glucan content $\left(32 \mathrm{~g} \mathrm{~kg}^{-1}\right)$ in trial 2 similar to 'Maali' in trial 1. 'Kornelija' had the highest protein content (108 g $\left.\mathrm{kg}^{-1}\right)$ in trial and also good level of starch $\left(644 \mathrm{~g} \mathrm{~kg}^{-1}\right)$ and $\beta$-glucan $\left(37 \mathrm{~g} \cdot \mathrm{kg}^{-1}\right)$.

\section{DISCUSSION}

Several investigations have shown that the grain yield and quality characteristics of barley are substantially influenced by genotype, environmental factors and their interactions (Åman and Newman, 1986; Conry, 1994; Oscarsson et al., 1998). The previous studies carried out in Baltic region have shown similar results. Leistrumaite and Paplauskiene (2005) found that the grain yield and quality traits of spring barley varieties vary greatly due to growing conditions. Significant effect of year as a factor to HB grain yield was observed in previous research carried out at Stende (Bleidere et al., 2012). Bleidere et al., (2013) found significant influence of genotype and nitrogen supply to the HB yield and quality characteristics. In the present study we show the significant effect of both tested environmental factors (locations and year) to grain yield and food quality characteristics of barley. Co-effect of factors indicated different reaction of genotypes to the variation of growing conditions.

The effect of nutrient supply, amount of precipitation and temperature to grain yield of cereals is well known. For example the results of the studies of Conry (1994) showed substantial lowering of the grain yield in cases of drought, compared to the yields in conditions of sufficient precipitation. Bleidere et al. (2013) concluded that moisture regime during the tillering stage of a particular year can influence the effectiveness of barley varieties to use nitrogen for increasing yield. In the present study, the effect of location and year as factors to variation of barley grain yield were superior compared to the effect of genotype.

Starch, protein and $\beta$-glucan are the major components of barley grain (Åman and Newman, 1986). Starch is the prin- 
cipal component of yield in barley and contributes between 600 and $750 \mathrm{~g} \cdot \mathrm{kg}^{-1}$ of final grain dry weight. Protein content of mature barley grains is typically between 90 and 130 $\mathrm{g} \cdot \mathrm{kg}^{-1}$ of total grain dry weight. The precise composition depends on growth conditions and on the rate and timing of nitrogen fertiliser application. High temperatures or water shortage increase the percentage of protein in the grain. In present study the starch and protein content of barley genotypes varied within the above mentioned interval. Oscarsson et al., (1998) found that protein content increased whereas starch content decreased while improving N supply. Shortage of moisture causes increase of protein and decrease of starch content (Åman and Newman, 1986). In this study protein content was more influenced by environmental conditions and starch content by genotype.

The content of $\beta$-glucan of barley grains was observed to range between $35-45 \mathrm{~g} \cdot \mathrm{kg}^{-1}$ in several studies (Åman and Newman, 1986; Perez-Vendrell et al., 1996; Oscarsson et al., 1998). In the present study the $\beta$-glucan content of tested genotypes varied from $32-42 \mathrm{~g} \cdot \mathrm{kg}^{-1}$. Powell et al., (1985) found that the content of $\beta$-glucan was more influenced by genotype than environmental conditions. Availability of sufficient moisture during grain filling is critical for formation of high $\beta$-glucan content (Hockett et al., 1987; Kasha and Falk, 1993). In this study, genotype, year and co-effect of these factors had similar effect on $\beta$-glucan content in trial 2. Co-effect of genotype and location showed the highest effect on variation of $\beta$-glucan followed by location and genotype in trial 1 .

Barley TKW and TW varied depending on genetic and environmental conditions according to the results of a study by Oscarsson et al. (1998). Bleidere et al. (2013) also found significant influence of these factors on barley TKW and TW. In the present study, TW was influenced mainly by genotype, and TKW by location in trial 1. Genotype, year and co-effect of these two factors had significant effect on variation of TW and TKW.

The hulless gene has multiple effects on many traits of barley, like yield reduction, lower seed weight and higher volume weight (Choo et al., 2001). The barley varieties suitable for human consumption should ideally contain high content of $\beta$-glucan, protein, and soluble non-starch polysaccharides. The hulless barley is more desirable for food purposes (Holtekjølen et al., 2006).

In this study the HB genotypes showed lower yield, higher protein and TW, compared to those of $\mathrm{CB}$ varieties. The HB varieties generally had higher $\beta$-glucan content than the covered barley cultivars. In this study the $\mathrm{CB}$ variety 'Maali' showed high $\beta$-glucan content, which was superior to that of HB genotypes.

Results of the study showed significant effect of genotype, environment (location and yield) and co-effect of these factors on grain yield and food quality characteristics of barley grown in organic management conditions. The contribution of factors in explaining the variation of different quality characteristics varied. Tested genotypes differed in yield and quality characteristics. The CB variety 'Maali' showed good adaptation over locations, having high yield, $\beta$-glucan content and TKW. Line '1165' and the variety 'Kornelija' outweighed the other $\mathrm{HB}$ genotypes according to the integral evaluation method.

\section{ACKNOWLEDGEMENTS}

This research was financed by the European Social Fund Project No. 2013/0072/1DP/1.1.1.2.0/13/APIA/VIAA/032.

\section{REFERENCES}

Åman, P., Newman, C. W. (1986). Chemical composition of some different types of barley grown in Montana, USA. J. Cereal Sci., 4, 133-141.

Ames, N., Rhymer, C., Rossnagel, B., Therrien, M., Ryland, D., Dua, S., Ross, K. (2006). Utilization of diverse hulless barley properties to maximize food product quality. Cereal Foods World, 51 (1), 23-28.

Ames, N. P., Rhymer C. R. (2008). Issues surrounding health claims for barley. J. Nutr., 138, 1237-1243.

Baik, B.-K., Ullrich, S. E. (2008). Barley for food: Characteristics, improvement, and renewed internest. J. Cereal Sci., 48, 233-242.

Behall, K. M., Scholfield, D. J., Hallfrisch, J. (2004). Diets containing barley significantly reduce lipids in mildly hypercholesterolemic men and women. Amer. J. Clin. Nutr., 80, 1185-1193.

Bhatty, R. S., (1993). Nonmalting uses of barley. In: MacCregor, A. W., Bhatty, R. S. (eds.). Barley: Chemistry and Technology. American Association of Cereal Cemists, St. Paul, MN, pp. 355-417.

Biel, W., Jacyno, E. (2013). Chemical composition and nutritive value of spring hulled barley varieties. Bulgarian J. Agr. Sci., 19 (4), 721-727.

Bleidere, M., Mežaka, I., Legzdina, L., Grunte, I., Beinarovica, I., Rostoks, N. (2012). Variation of spring barley agronomic traits significant for adaptation to climate change in Latvian breeding programmes. Proc. Latvian Acad. Sci., Section B, 66 (1/2), 30-35.

Bleidere, M., Zute, S., Brunava, L., Bobere, N., Jākobsone, I. (2013). Yield and grain quality of hulless spring barley in field trials under different nitrogen management conditions. Proc. Latvian Acad. Sci., Section B, 67 (3), 229-235.

Cavallero, A., Empilli, S., Brighenti, F., Stanco, A. M. (2002). High(1-3, $1-4)-\beta$-glucan barley fractions in bread making and their effects on human glucemic response. J. Cereal Sci., 36, 59-66.

Choo, T., Ho, K. M., Martin, R. A. (2001). Genetic analysis of hulless x covered cross of barley using doubled-haploid lines. Crop Sci., 41, 1021-1026.

Conry, M. J. (1994). Comparative effect of six cultivars at four rates of nitrogen on the grain yield and quality of spring-sown malting barley in Ireland. J. Agr. Sci., 122, 343-350.

Fastnaught, C. E. (2001). Barley fiber. Ch. 27, In: Handbook of Dietary Fiber. Cho, S., Dreher, M. (eds.). Marcel Dekker, New York, pp. 519-542.

Grissom, R. J., Kim, J. J. (2012). Effect Sizes for Research: Univariate and Multivariate Applications. $2^{\text {nd }}$ ed. Taylor \& Francis Group, New York. 429 pp.

Hockett, E. A., McGuire, C. F., Newman, C. W. (1987). The relationship of barley $\beta$-glucan content to agronomic and quality characteristics. Proceedings of the $5^{\text {th }}$ International Barley Genetics Symposium, 6-11 October 1986, Okayama, Japan. Sanyo Press, Okayama, pp. 851-860.

Holtekjølen A. K., Uhlen, A. K., Brathen, E., Sahlstrøm, S., Knutsen, S. H. (2006). Contents of startch and non-startch polysaccharides in barley varieties of different orogin. Food Chem., 94, 348-358.

Izydorczyk, M. S., Storsley, J., Labossiere, D., Macgregor, A. W., Rossnagel, B. G. (2000). Variation in total and soluble $\beta$-glucan content in 
hulless barley: Effects of thermal, physical, and enzymic treatments. $J$. Agr. Food Chem., 48, 982-989.

Johansson, E., Nilsson, A. C., Östman, E. M., Björck, M. E. (2013). Effects of indigestible carbohydrates in barley on glucose metabolism, appetite and voluntary food intake over $16 \mathrm{~h}$ in healthy adults. Nutr. J., 12 (46), 2-11.

Kasha, K. J., Falk, D. E. (1993). Potential improvement of barley quality through genetic enginering. In: Barley: Chemistry and Technology. American Association of Cereal Cemists, St. Paul, MN, pp. 419-433

Leistrumaite, A., Paplauskiene, V. (2005). Genetic resources of spring barley: Screening for yield stability and grain malt quality traits. Biologija, $\mathbf{3}$, 23-26.

Martynov, S. (1987). Method of multi-criteria breeding of plants [Мартынов, С. П. Метод многокритериального выбора на заключительном этапе селекции растений]. Sel'skohozyaistvennaya Biologija [Сельскохозяйственная биология], № 6, 122-124 (in Russian).

Mežaka, I., Bleidere. M., Legzdina, L., Rostoks, N. (2011). Whole genome association mapping identifies naked grain locus $N U D$ as determinant of $\beta$-glucan content in barley. Agriculture, 98 (3), 283-292.

Newman, R. K., Lewis, S. E., Newman, C. W., Boik, R. J. (1989). Hypercholesterolemic effect of barley foods on healthy men. Nutr. Rep. Int., 39, 749-760.

Received 3 May 2015
Newman, C. W., Newman, R. K. (2006). A brief history of barley foods. Cereal Foods World, 51, 4-7.

Oscarsson, M., Andersson, R., Åman, P., Olofsson, S., Jonsson, A. (1998). Effects of cultivar, nitrogen fertilization rate and environment on yield and grain quality of barley. J. Sci. Food Agr., 78, 359-366.

Perez-Vedrell, A. M., Brufau, J., Molina-Cano, J. L., Francesch, M., Guasch, J. (1996). Effect of cultivar and environment on $\beta-(1,3)-(1,4)-D-$ glucan content and acid extract viscosity of Spanish barleys. J. Cereal Sci., 23, 285-292.

Pins, J. J., Kaur, H. (2006). A review of the effects of barley $\beta$-glucan on cardiovascular and diabetic risk. Cereal Food World, 51, 8-11.

Powell, W., Caligari, P. D. S., Swanston, J. S., Jinks, J. L. (1985). Genetic investigations into $\beta$-glucan content in barley. Theor. Appl. Gen., 71, 461-466.

Quinde, Z., Ullrich, S. E., Baik, B.-K. (2004). Genotypic variation in colour and discolouration potential of barley-based food products. Cereal Chem., 81, 752-758.

Thomason, W. E., Phylips, S. B., Warren, J. A., Alley, M. M. (2012). Winter hulless barley response to nitrogen rate and timing and foliar phosphorus. $J$. Plant Nutr., 35 (2), 225-234.

Valaja, J., Suomi, K., Alaviuhkola, T., Mela, T. (1997). Effects of variety, soil, type and nitrogen fertilizer supply on the nutritive value of barley for growing pigs. Agr. Food Sci. Finland, 6, 295-303.

\section{MIEŽU PAZĪMJU MAINĪBA ĢENĒTISKO UN VIDES APSTĀKL̨U IETEKMES REZULTĀTĀ UN VIETĒJO GENOTIPU PIEMĒROTĪBA PĀRTIKAS RAŽOŠANAI}

Pētījuma mērḳis bija novērtēt ražas un kvalitātes pazīmju mainību plēkšņgraudu un kailgraudu miežu genotipiem ğenētisko un vides apstākḷu ietekmē bioloǵiskās saimniekošanas apstākḷos. Tika veikti divi dažādi lauka eksperimenti: 2014. gadā kailgraudu miežu genotipi 'Kornelija', 'Irbe', '1165', '1185' un plēkšn,graudu škirnes 'Ansis' un 'Maali' novērtēja trīs dažādās vietās — Stendē, Priekul,os (Latvijā) un Jegevā (Igaunijā). Škirnes 'Ansis' un 'Kornelija', līnijas '1165' un '1185' bija iekḷautas arī otrajā lauka eksperimentā Stendē, kas ilga trīs gadus (2011-2013). Genotips un vides apstākḷi (vieta un gads) kā arī šo faktoru mijiedarbības būtiski ietekmēja ražas un graudu kvalitātes pazīmju mainību miežu genotipiem. Taču pastāvēja būtiskas ietekmes atškirības starp analizētajām pazīmēm. Graudu ražu vairāk ietekmēja vides apstākḷi nekā genotips. Plēkšņu saturu un graudu tilpummasu vairāk ietekmēja genotips nekā faktors. Lai salīdzinātu miežu genotipus un identificētu labākos (ar mazāko novirzi no vēlamās pazīmes vērtības), tika izmantota integrētās novērtēšanas metode. Plēkšn,graudu miežu šķirne 'Maali' parādīja labu adaptivitāti dažādos vides apstākḷ̆os, dodot labu ražu, augstu $\beta$-glikāna saturu graudos un tūkstots graudu masu. Šķirne 'Kornelija' un līnija '1165' parādīja labākos rezultātus starp kailgraudu miežu škirnēm. 